\title{
MENINGKATKAN DISIPLIN BELAJAR SISWA MELALUI KONSELING KELOMPOK DENGAN STRATEGI MODELING
}

\author{
Dewi Nurmalika \\ SMA NU Gombengsari Banyuwangi \\ bimaabda28@gmail.com \\ Prabandari Nuansmahira \\ SMK Negeri 1 Bandung Tulungagung \\ pnuansmahira6@gmail.com
}

\begin{abstract}
Abstrak
Tujuan penelitian ini untuk mengetahui disiplin belajar siswa dapat ditingkatkan dengan strategi self management pada siswa kelas X SMA NU GOBENGSARI. SMA NU GOMBENGSARI. Subjek yang diteliti adalah kelas $X$ di SMA NU Gombengsari dengan tingkat disiplin belajar yang rendah. Siswa kelas X seluruhnyabrjumlah 30 orang, yang menjadi subjek penelitian berjumlah 8 siswa, masuk dalam kategori disiplin belajar rendah. Instrument pengumpul datayang digunakan adalah angket rendah diri. berdasarkan dengan data yang dieliti, penelitian ini tergolong penelitian kuantitatif dengan menggunakan metode pre eksperimental. Metodel analisis yang digunakan adalah statistic non parametic yaitu uji jumlah yang mendapatkan skor paling rendah. Dapat diketahui pada tabel binominal. Strategi self management mampu meningkatkan disiplin belajar siswa yang ditunjukan melalui skor angket disiplin belajar siswa antara sebelum dan sesuadah diberikan treatmen menggunakan strategi self management.
\end{abstract}

Kata kunci: strategiself-management, disiplin belajar

\begin{abstract}
The purpose of this study was to determine the use of self-management strategies to improve learning discipline. The research location is located at SMK Negeri $Z$ Banyuwangi. This research is a pre-test-post-test one group design. The data collection tool used was a questionnaire. The subjects in this study were eight grade $X$ students who have low learning discipline. The data analysis technique used is non-parametric statistics using the Wilcoxon test with a significant level of 5\%, indicating that there are differences in the scores of students' learning discipline levels before and after the use of self-management group counseling. This means that self-management group counseling can be used to overcome student learning disciplines. So the hypothesis put forward in this study which reads "the use of group counseling can significantly improve the learning discipline of class $X$ students of SMA NU GOMBENGSARI Banyuwangi in the academic year 2020/2021." acceptable.

Keywords: strategic self-management, learning discipline
\end{abstract}




\section{LATAR BELAKANG}

Disiplin belajar tinggi merupakan faktor yang sangat penting dalam pengaktualisasian diri peserta didik untuk mencapai perkembangan diri yang maksimal. Adapun pengertian dari disiplin belajar adalah ketundukan anak didik terhadapt peraturan-peraturan yang tanpa menyukurkan peroses belajar (Sumantri, 2010).

Berdasarkan hasil analisis tim BK dan masukan dari tim kesiswaan di SMA NU Gondangsari tingkat disiplin belajar siswa selalu mengalami kenaikan dari tahun ketahun, yaitu mencapai $8 \%$ tiap tahunya.

Hal ini dapat diketahui dengan seringnya siswa terlambat masuk sekolah, seringnya ketidak hadiran siswa dalam pelajaran dan selalu acuh dalam kegiatan belajar.

Hal-hal tersebut terjadi karena disebabkan oleh faktor insternal dan eksternal. Permasalahn tersebut jika dibiarkan berlatut-larut akan menyebabkan dampak yang membahayakan bagi kegiatan belajar siswa bahkan sampai kegagalan siswa dalam menuntaskan pendidikan di sekolah. Oleh karena itu peningkatan disiplin belajar siswa sangat menentukan terwujudnya kepribadian yang optimal.
Untuk meningkatkan disiplin belajar siswa peneliti memilih salah satu strategi dalam layanan bimbingan konseling yaitu Strategi self managemant yang diangap cocok untuk meningkatkan didiplin belajar pada siswa.

Konseling kelompok selfmanagement adalah layanan dalam bimbingan konseling dari konselor yang diberikan kepada sekelompok siswa/konseli untuk menyelesaikan masalahnya dengan cara pengondisian/pengaturan perilaku diri sendiri.

Dengan uraian di atas peneliti ingin menguji apakah strategi self management signifikan dapat mneningkatkan disiplin belajar siswa kelas $\mathrm{X}$ SMK NU Gondangsari.

\section{METODOLOGI}

Pendekatan yang diterapkan adalah kuantitatif deskriptif. Kasiram (Wijaya, 2018) mengutarakan bahwa penelitian kuantitatif merupakan penelitian yang berfokus pada angkaangka sebagai suatu alat dalam menganalisis fenomena maupun keterangan di lapangan untuk diketahui yang sebenarnya. 
Adapun jenis penelitian yaitu preeksperimental design Menurut Sugiyono (2015) "penelitian yang dengan metode eksperimen dapat dikatakan sebagai suatu cara yang menggunakan perlakuan tertentu dalam melihat seberapa besar pengaruh yang ditimbulkan dalam sautu penelitian, termasuk dalam kondisi apapun dan dengan keadaan yang tidak terkendalikan." Maka dari itu, bentuk rancangan penelitian ini menggunakan one group pretest-posstest design. Maksud dari bentuk one group pretestposstest design yaitu, suatu kelompok diberikan tes diawal dan diakhir disamping perlakuan, kelompok tidak adanya kelompok pembanding, pasangan atau diambil secara acak, namun dibentuk suatu kelompok yang sama untuk diberikan perlakuan seterusnya.

Penelitian ini menggunakan populasi peserta didik di keals X SMA NU Gombengsari dengan siswa sebayak 30 orang siswa. Subjek yang diberikan treatmen yaitu terdiri dari 8 orang siswa yang telah dikategorikan berada pada disiplin belajar yang rendah.

Menurut Sutoyo (Belluano dkk, 2019) angket adalah sejumlah pernyataan yang tertulis tentang fakta, opini serta data faktual yang berkaitan langsung dengan diri responden, yang perlu dijawab oleh responden untuk mengetahui kebenarannya. Selain itu, untuk mengetahui signifiikansi antara sebelum dan sesudah perlakuan terhadap disiplin belajar, yaitu dengan menggunakan teknik analisis data yaitu melalui norma kategori dan SPSS (statistical Product and Service.

\section{HASIL PENELITIAN}

Peneliti telah melewati proses persiapan yang sistematis dan matang. Sebelum memulai penelitian, tahapan awal yang dilakukan adalah menyangkut mengenai pemberian izin penelitian, menyusun instrumen penelitian dan modul eksperimen yaitu sebagai panduan atau petunjuk yang akan digunakan pada saat melaksanakan penelitian dalam melakukan treatment. Pengumpulan data dan penelitian dilakukan kurang lebih yaitu dari tanggal 12 Agustus sampai dengan 05 oktober 2020. Hasil penelitian diperoleh yaitu dengan mengabungkan dua data yang di dapat yakni hasil pretest dan posttest.

Berdasarkan hasil angket pengukuran terhadap 30 siswa SMA NU Gombengsari, diketahui 8 siswa yang memiliki tingkat disiplin belajar yang 
rendah. Selanjutnya ke delapan siswa yang displin belajarnya rendah tersebut diberikan bantuan perlakuan berupan strategi self management.

Tabel 1 Subjek Skor Disiplin Belajar Rendah

\begin{tabular}{llll}
\hline No & Inisial & Skor & Kategori \\
\hline 1 & RF & 36 & Rendah \\
\hline 2 & FD & 35 & Rendah \\
\hline 3 & AD & 37 & Rendah \\
\hline 4 & AM & 39 & Rendah \\
\hline 5 & HA & 33 & Rendah \\
\hline 6 & SS & 42 & Sedang \\
\hline 7 & AA & 39 & Rendah \\
\hline 8 & MR & 36 & Rendah \\
\hline
\end{tabular}

Pemberian treatment konseling kelompok self management dilaksanakan selama 8 kali pertemuan (termasuk pretest dan posttest) yang diikuti oleh 8 orang siswa, maka hasil pretest mengenai gambaran disiplin belajar siswa sesudah diberikan konseling kelompok selfmanagement adalah sebagai berikut ini:

Tabel 2 Skor Hasil Post- test

\begin{tabular}{llll}
\hline No & Inisial & Skor & Kategori \\
\hline 1 & RF & 62 & Tinggi \\
\hline 2 & FD & 61 & Tinggi \\
\hline 3 & AD & 60 & Tingggi \\
\hline
\end{tabular}

\begin{tabular}{llll}
\hline 4 & AM & 56 & Sedang \\
\hline 5 & HA & 54 & Sedang \\
\hline 6 & SS & 46 & Sedang \\
\hline 7 & AA & 50 & Sedang \\
\hline 8 & MR & 60 & Tinggi \\
\hline
\end{tabular}

\section{PEMBAHASAN}

Perbandingan disiplin belajar siswa Sebelum dan Sesudah diberikan Tindakan Konseling KelompokSelf-Management.

Berdasarkan hasil pemberian treatment konseling kelompok selfmanagement sebanyak 8 pertemuan (termasuk pretest dan posttest) mengalami perubahan dan peningkatan skor disiplin belajar yang signifikan. Hal tersebut dapat dilihat berdasarkan hasil posttest disiplin belajar yang dibandingkan dengan hasil pretest disiplin belajar yang mempunyai perbandingan nilai rata-rata yang sangat signifikan. Perbandingan skor sebelum dan sesudah treatmen terurai seperti dibawah ini:

Tabel 1.3 Hasil Pre-test dan Post-test

\begin{tabular}{|c|c|c|c|c|}
\hline $\begin{array}{l}\mathrm{N} \\
\mathrm{O}\end{array}$ & $\begin{array}{l}\text { INISI } \\
\mathrm{AL}\end{array}$ & $\begin{array}{l}\text { PRETE } \\
\text { ST }\end{array}$ & $\begin{array}{l}\text { POSTT } \\
\text { EST }\end{array}$ & $\begin{array}{l}\text { Peningk } \\
\text { atan } \\
\text { skor }\end{array}$ \\
\hline 1 & $\mathrm{RF}$ & 36 & 62 & 26 \\
\hline 2 & FD & 35 & 61 & 26 \\
\hline
\end{tabular}




\begin{tabular}{lllll}
\hline 3 & AD & 37 & 60 & 23 \\
\hline 4 & AM & 39 & 56 & 17 \\
\hline 5 & HA & 33 & 54 & 21 \\
\hline 6 & SS & 42 & 46 & 4 \\
\hline 7 & AA & 39 & 50 & 11 \\
\hline 8 & MR & 36 & 60 & 24 \\
\hline & Jumla & 297 & 449 & 152 \\
& h & & & \\
\hline & Rata- & 37 & 56 & 19 \\
& Rata & & & \\
\hline
\end{tabular}

Dari tabel perhitungan perbandingan pretest daan posttest diatas dapat dijelaskan bahwa subjek yang diberikan perlakuan (treatment) mengalami peningkatan skor rata-rata adalah 19 , skor rata-rata pre-test adalah 37 dan setelah diberikan perlakuan (treatment) skor pada subjek meningkat dengan rata-rata skor post-test sebesar 56 . Peningkatan skor paling tinggi dicapai oleh subjek "RF dan FD" dengan peningkatan sebanyak 26, sedangkan penurunan skor paling sedikit yaitu sebanyak 4 oleh subjek "SS".

Tahapan selanjutnya adalah dengan melakukan uji data yaitu dengan menguji hipotesis penelitian menggunakan rumus Wilxocon Rank Test untuk mencari perbedaan skor antara sebelum dan sesudah serta untuk melihat sejauh mana penurunan skor dari keberhasilan strategi self management untuk meningkatkan disiplin belajar. Jadi, Wilxocon Rank Test merupakan bagian Statistic Nonparametric, karena jumlah sampel ini yaitu cuma 8 orang siswa, sehingga data tidak normal (Uyanto, 2009). Uji hipotesis menggunakan rumus Wilcoxon Rank Test.

Dari hasil analisis di atas hipotesis yang diajukan yaitu strategi self management singnifikan untuk meningkatkan disiplin belajar siswa kelas X SMK NU Gombengsari, diterima.

\section{KESIMPULAN}

Dari analisis data telah disimpulkan bahwa strategi self management singnifikan untuk meningkatkan disiplin belajar siswa kelas $\mathrm{X}$ SMA NU GOMBENGSARI dengan uraian sebagai berikut: (1) hasil pretest yang diberikan kepada 30 orang siswa, yaitu diperoleh 8 orang siswa kategori disiplin belajar rendah dan. Kemudian di treatment menggunakan strategi self management. (2) Gambaran dari hasil posttest yaitu setelah diberikan treatment mengalami peningkatan yang signifikan, dengan peningkatan skor 152. (3) Terdapat perubahan antara sebelum dan 
sesudah

diberikannya treatment

(perlakuan), yaitu dengan peningkatan skor 152 artinya tidak terdapat lagi siswa yang kategori skor disiplin belajar rendah.

\section{SARAN}

Dengan terselesaikannya kegiatan ini, maka peneliti mengajukan saran: Bagi guru BK diharapkan hasil penelitian ini sebagai rujukan dalam mereduksi permasalahan disiplin belajar siswa dengan strategi self management. Bagi siswa di SMA NU Gombengsari yang mengalami peningkatan disiplin belajar untuk dipertahankan meskipun proses treatmen sudah berakhir dan diaplikasikan dalam keseharian dalam mengikuti kegiatan belajar.

Bagi penelitian selanjutnya, yaitu diharapkan dapat melakukan dengan menggunakan siswa yang berada di daerah selain perkotaan, menambahkan subjek penelitian, dan mempertimbangkan waktu pelaksanaan dengan kondisi yang efisien serta menambahkan penggunaan instrumen seperti wawancara agar hasil penelitian lebih akurat. Sehingga mendapatkan perubahan secara menyeluruh.

\section{DAFTAR RUJUKAN}

Azwar, Saifuddin. 2017. Metode Penelitian Psikologi Edisi 2. Yogyakarta: Pustaka Pelajar.

Bela, Hadi. 2017. Meningkatkan disiplin belajar siswa melaui management kelas Jurnal Pendidikan Managemant Perkantoran, Vol. 02 No. 02 (diakses 15 Januari 2020).

Isnaini, Faiqotul dan Tufik. 2015. Strategi Self Management untuk Meningkatkan Kedisiplinan Siswa. Jurnal Penelitian Humaniora, Vol. 16 No. 02.

Sugiono. 2014. Metode Penelitian Kuantitatif, Kualitatif. Jakarta: Alfabeta. 